Institute of $\mathbf{F}_{\text {ood and }} \mathbf{A}$ gricultural $\mathbf{S}_{\text {ciences }}$

\title{
Warm Climate Production Guidelines for Bougainvillea ${ }^{1}$
}

Richard Schoellhorn and Erin Alvarez ${ }^{2}$

\section{Introduction}

Common Name: Bougainvillea, Paper Flower

Scientific Name: Bougainvillea glabra

Family: Nyctaginaceae

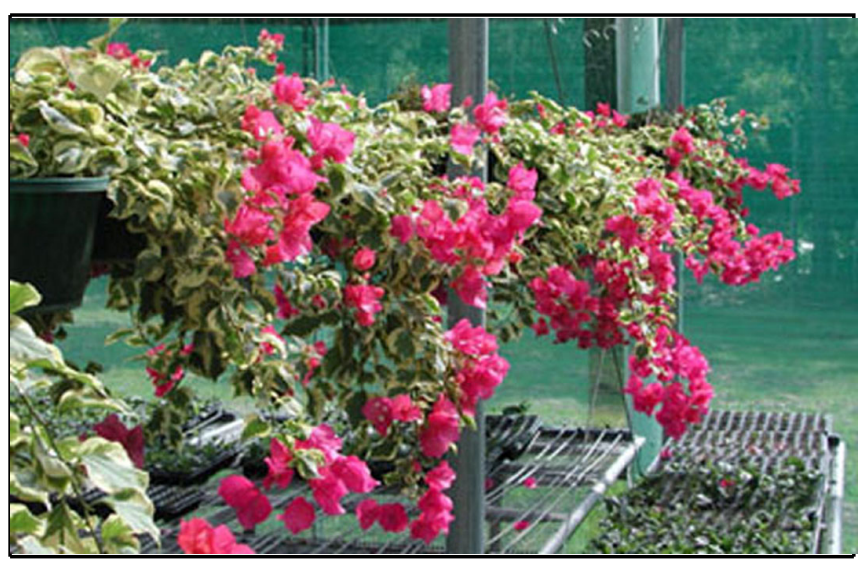

Figure 1.

Along with palms, sunshine, and beaches, the cascading blooms of Bougainvillea provide one of Florida's signature tropical images (See Figure 1). As a profuse bloomer, Bougainvillea is most striking during the winter, when it is at its peak and few other plants are able to provide color. Although it is frost-sensitive and hardy in zones $9 \mathrm{~b}$ and 10 , Bougainvillea can be used as a houseplant or hanging basket in cooler climates. In the landscape, it makes an excellent hot season plant, and its drought tolerance makes Bougainvillea ideal for warm climates year-round. Native to the coasts of Brazil, Bougainvillea has a high salt tolerance, which makes it a natural choice for south Florida and other coastal regions. As a woody clambering vine, Bougainvillea will stand alone and can be pruned into a standard, but it is perfect along fence lines, on walls, in containers and hanging baskets, and as a hedge or an accent plant. Its long arching branches are thorny, and bear heart-shaped leaves and masses of papery bracts in white, pink, orange, purple, and burgundy (See Table 1). Many cultivars, including double flowered and variegated, are available (See Table 2).

\section{Production}

\section{pH Preference}

Bougainvillea does best with a slightly acidic soil $\mathrm{pH}$ of 5.5-6.0.

\section{Media}

Bougainvillea has an extremely fine root system, and should be planted in well-drained soils. Avoid soil mixes with high peat levels and water retention. These types of media retain too much water and will

1. This document is ENH 874, one of a series of the Environmental Horticulture Department, Florida Cooperative Extension Service, Institute of Food and Agricultural Sciences, University of Florida. Original publication date October 1, 2002. Visit the EDIS Web Site at http://edis.ifas.ufl.edu.

2. Richard Schoellhorn, Associate Professor; Erin Alvarez, Student Assistant, Environmental Horticulture Department, Institute of Food and Agricultural Science, University of Florida, Gainesville, Fl 32611.

The Institute of Food and Agricultural Sciences is an equal opportunity/affirmative action employer authorized to provide research, educational information and other services only to individuals and institutions that function without regard to race, color, sex, age, handicap, or national origin. For information on obtaining other extension publications, contact your county Cooperative Extension Service office. Florida Cooperative Extension Service/Institute of Food and Agricultural Sciences/University of Florida/Christine Taylor Waddill, Dean. 
contribute to root rot; be sure to select a well-draining media.

\section{Light Levels}

As a tropical plant, Bougainvillea requires full sun, or a light level of at least 4000 f.c. Most growers keep hanging baskets at the top of the greenhouse for maximum light exposure.

\section{Production Temperatures}

Temperatures should be maintained somewhat high; a minimum of $65^{\circ} \mathrm{F}$ at night and $75^{\circ}$ to $95^{\circ} \mathrm{F}$ during the day. Crop scheduling will be delayed at cool temperatures, especially if the soil is also cool.

\section{Fertilization}

At planting, provide a fertilizer that is high in phosphate, and follow with a balanced liquid fertilizer at $150-300 \mathrm{ppm}$. Nitrogen and phosphate are critical to flowering, but do not overfertilize; too much fertilizer will add growth, but will inhibit blooming. Magnesium and iron deficiencies are common, but apply a complete micronutrient blend or chelated spray with caution, as too much of either Mn or Fe will cause the other to be unavailable to the plant, and will result in a deficiency. Micronutrient applications can be used at $1 / 2$ the recommended rate at two times to avoid toxicity.

\section{Propagation}

Propagate this plant from cuttings, but propagation can be slow and difficult due to Bougainvillea's extremely fine root system. Bougainvillea roots best from semi-hardwood cuttings 5-9 nodes in length. Take softwood cuttings if you are propagating when night temperatures are above $55^{\circ}$; hardwood cuttings when night temperatures are below $55^{\circ} \mathrm{F}$. Treat cuttings with between 3000 and 6000 ppm IBA. Remove leaves from all portions of the stem that will be underground. Some research suggests that thicker cuttings with higher concentrations of auxin produce better rooting; however, high levels of auxin may result in stunted branching. Bottom heat will speed rooting. Intermittent overhead mist is required; cuttings must never be allowed to wilt. High relative humidity must be maintained around the plants at all times. Time to rooting is 6-12 weeks. Transplant young plants with caution to avoid damaging the roots, and always apply a broad-spectrum fungicide drench when planting cuttings and again after transplanting to prevent root rot.

\section{Pinching Required}

Pinch plants at 4 weeks to shape them, or pinch to a stake for taller plants. Dikegulac can be used at 2 $\mathrm{fl} \mathrm{oz/gal,} \mathrm{or} \mathrm{Atrimmec}{ }^{\circledR}$ at $1 \mathrm{fl} \mathrm{oz} / \mathrm{gal}$ for a chemical pinch that will stimulate new branch growth and subsequent flowering.

\section{Plant Growth Regulators}

The need for and effects of plant growth regulators vary greatly depending on a number of factors. It is always recommended that growers test plant growth regulators before use. Always follow label instructions. Growers have reported success with Paclobutrazol at 20-40 ppm when plants are near salable size.

\section{Photoperiod/Flowering}

Blooms occur only on new growth, so new growth on plants is vital to the achievement of flowering. Bougainvillea normally flowers during the short days of winter, but blooms are highly dependent on temperature. Drought stress can also stimulate flowering even with long daylight exposure. Growers frequently allow plants to dry just to the point of wilting to induce flowering. However, excessive drying can cause leaf drop and dormancy; use care and be sure to water at first signs of wilt.

\section{Plants Per Pot}

Plant one liner per gallon container, one or two liners for an eight inch hanging basket, and three liners per ten- to twelve-inch hanging basket.

\section{Scheduling}

Allow twelve to sixteen weeks for Bougainvillea to grow from a liner to a finished one-gallon plant or hanging basket, depending on temperature and light levels. (See Table 1) 


\section{Common Problems}

- Irregular flowering is a major concern for growers, who often use drought stress to encourage blooming. Variety choice can be extremely helpful in remedying this problem, however.

- Leaf drop can be a problem as a result of over-watering, under-watering, low light levels, or cold temperatures.

- Root rot is easily prevented by careful handling and by the application of a broad spectrum fungicide drench during transplanting or planting in the landscape.

- New growth yellowing or chlorosis is often a result of a magnesium or iron deficiency, and an application of a complete micronutrient blend or chelated spray should help, but use caution-too much of either $\mathrm{Mn}$ or Fe will result in a secondary deficiency, as the plant is unable to absorb one when the other is present at high levels.

- For old growth chlorosis, apply Epsom salts at 1-2 tsp/gal as a drench or foliar spray.

\section{Landscape Culture}

Bougainvillea is a wonderful addition to any landscape, whether it's used as a permanent fixture, a container plant or hanging basket in a semi-tropical landscape, or an annual in cooler climates. For the best performance out of your Bougainvillea, follow these guidelines:

- Keep Bougainvillea on the dry side, especially if you want lots of blooms. Too much water will promote root rot and cause leaves to drop. Don't water on cool nights.

- Use a high-bloom fertilizer.

- Plant or place Bougainvillea in full sun. As a potted plant, flowers will last for up to eight weeks if kept in a sunny location.

- Winter dieback may be a problem if the weather gets too cool, so if you're growing Bougainvillea in a frost-prone area, plant in a protected

location or cover in case of frost.

\section{Other Resources for Bougainvillea Information}

"http://hendry.ifas.ufl.edu/

HCHortNews_Bougainvillea.htm"

"http://www.bougainvilleas.com/"

"http://pine.usask.ca/cofa/departments/hort/hortinfo/ plants/bougainv.html"

"http://bougainvillea.freeyellow.com/ bougainvillea.html" 
Table 1. Rough table of production times for Bougainvillea

\begin{tabular}{|l|l||}
\hline \hline Time & Stage of Production \\
\hline $6-12$ weeks & Rooting/propagation - depending on propagation techniques \\
\hline $12-16$ weeks & 1 - Liner to gallon \\
\hline $12-16$ weeks & $1-2$ Liners per 8" hanging basket \\
\hline $14-20$ weeks & 3 - Liners per 10-12" hanging basket \\
\hline $20-50$ weeks & Liner to 3-5 gal nursery containers \& trellises \\
\hline $50-100$ weeks & From liner to larger nursery containers and specimen plants \\
\hline *Actual production time varies with light, temperature, and fertilizer regimens. \\
\hline
\end{tabular}

Table 2. Commonly produced Bougainvillea Cultivars and their primary uses

\begin{tabular}{|c|c|}
\hline \multicolumn{2}{|r|}{ For Landscape Use } \\
\hline 'Barbara Karst' & $\begin{array}{l}\text { Large bright red bracts. A most popular standby that always performs well. Almost constant } \\
\text { bloomer. }\end{array}$ \\
\hline 'Mrs Butt' & Red to peach bracts. This is a buttiana cultivar. Large repeat bloomer. \\
\hline 'Tropical Bouquet' & Orange but quickly becomes pink. Compact and bushy. \\
\hline 'California Gold' & $\begin{array}{l}\text { Large, long-lasting gold bracts. Can be considered as yellow in some environments. Nice vining } \\
\text { habit. }\end{array}$ \\
\hline 'Royal Purple' & Dark purple bracts. Good replacement for Elizabeth Angus in humid areas. \\
\hline \multicolumn{2}{|r|}{ For Containers/Hanging Baskets } \\
\hline 'Helen Johnson' & A dwarf red. Compact and bushy grower. Branches freely. Good for hanging baskets. \\
\hline 'Juanita Hatten' & $\begin{array}{l}\text { Red Foilage may be slightly variegated in shades of green. Branches freely. Good for hanging } \\
\text { baskets. }\end{array}$ \\
\hline 'Pink Pixie' & True miniature. Small pink bracts. Good for small pots. \\
\hline 'Summer Snow' & Large, pure white bracts. Excellent for weddings. Does very well in hanging baskets. \\
\hline 'Dr. David Barry' & Large lavender bracts. Fine for containers. \\
\hline
\end{tabular}


Table 2. Commonly produced Bougainvillea Cultivars and their primary uses

\begin{tabular}{||l|l||}
\hline \hline 'Raspberry Ice' & Red. Variegated foliage. Slow grower. Repeat bloomer. \\
\hline 'Double Pink' & Huge clusters of bright pink doubles. Repeat bloomer. \\
\hline 'Surprise' & Free blooming pink which may sport white flowers. \\
\hline 'Vicky' & Pink bracts. Leaf centers creamy yellow - some white bracts may be sported. \\
\hline 'Golden Summer' & White. Variegated yellow-gold foliage. Repeat bloomer. \\
\hline 'Sweet Dream' & Leaves are completely gold, bracts are pale lavender. A thornless variety. \\
\hline \hline
\end{tabular}

